\title{
Isolasi dan identifikasi Staphylococcus Epidermidis pada susu sapi PFH penderita mastitis subklinis di Wukirsari, Cangkringan, Sleman, DIY
}

\section{Isolation and identification of Staphylococcus Epidermidis from subclinical mastitis in PFH dairy cow in Wukirsari, Cangkringan, Sleman, DIY}

\author{
Ervina Ryan Puspasari, Yanuartono*, Sri Hartati, Slamet Rahardjo, Alfarisa Nururrozi, dan \\ Soedarmanto Indarjulianto
}

Fakultas Kedokteran Hewan Universitas Gadjah Mada

J1. Fauna No.2, Karangmalang, Depok, Sleman. 55281 Yogyakarta

Submitted: 28 January 2018, Accepted: 17 July 2018

\begin{abstract}
ABSTRAK: Mastitis merupakan keradangan pada ambing, dapat terjadi secaraq klinis maupun subklinis. Salah satu penyebab mastitis adalah Staphylococcus epidermidis. Penelitianini bertujuan untuk mengisolasi dan mengidentifikasi bakteri Staphylococcus epidermidis pada sapi perah PFH penderita mastitis subklinis di Wukirsari, Cangkringan, Sleman, DIY. Enam belas sampel susu diuji dengan Californian Mastitis Test (CMT), kemudian dilanjutkan dengan inokulasi dalam Brain Heart Infussion (BHI), ditanam pada media plat agar darah (PAD) dan Mac Conkey Agar (MCA) selama 24 jam pada temperatur $37^{\circ} \mathrm{C}$. Koloni yang tumbuh kemudian ditanam pada media gula gula dan nutrient agar (NA). Pengecatan gram, uji katalase, uji koagulase dan uji DNase sebagai peneguhan bakteri. Hasil uji CMT menunjukkan 15 (93.75\%) dari 16 sampel susu positif menderita mastitis subklinis. Hasil isolasi menunjukkan 1 (6.66\%) dari 16 sampel positif terinfeksi Staphylococcus epidermidis. Hasil penelitian kejadian mastitis subklinis di daerah penelitian menunjukkan angka yang tinggi $(93,75 \%)$ dan disebabkan oleh tata kelola peternakan dan prosedur pemerahan yang masih kurang memadai. Tingginya kejadian mastitis subklinis tersebut kemungkinan disebabkan oleh bakteri yang lain karena hanya 6,66\% yang disebabkan oleh Staphylococcus epidermidis.
\end{abstract}

Kata kunci: Mastitis subklinis, Californian Mastitis Test, Staphylococcus epidermidis

ABSTRACT: Mastitis is an inflammation of the mammary gland, can be occured clinically or subclinically. One of the causes of mastitis is Staphylococcus epidermidis. This study was aimed to isolate and identify Staphylococcus epidermidis in subclinical mastitis PFH dairy cows in Wukirsari, Cangkringan, Sleman, DIY. Sixteen milk samples were tested with a Californian Mastitis Test (CMT), followed by inoculation in Brain Heart Infusion (BHI), planted on a blood agar plate plate (PAD) and Mac Conkey Agar (MCA) for 24 hours at $37^{\circ} \mathrm{C}$. The growing colonies were then grown on sugar sugar and nutrient agar (NA) media. Gram staining, catalase test, coagulase test and DNase test as bacteria confirmation.CMT test results showed $15(93.75 \%)$ out of 16 positive milk samples suffered from subclinical mastitis. Results of isolation showed 1 (6.66\%) of 16 positive samples infected with Staphylococcus epidermidis. The results of this study indicate that incidence of subclinical mastitis in the study area showed a high rate and is likely to be caused by inadequate management practices and milking procedures. The high incidence of subclinical mastitis is probably caused by other bacteria because only $6.66 \%$ is caused by Staphylococcus epidermidis.

Keywords: Subclinical mastitis, Californian Mastitis Test, Staphylococcus epidermidis

${ }^{*}$ Corresponding Author: yanuartono20@yahoo.com

DOI: 10.21776/ub.jiip.2018.028.02.04 


\section{PENDAHULUAN}

Salah satu wilayah yang memiliki banyak usaha peternakan sapi perah adalahWukirsari, Cangkringan, Sleman yang terletak di lerenggunung Merapi. Namun demikian, tatalaksana yang masih kurang memadai menjadi kendala utama dan kemungkinan besar berakibat pada tingginya kasus mastitis di wilayah tersebut. Mastitis merupakan masalah utama dalam usaha peternakan sapi perah, baik di negara maju maupun negara berkembang, termasuk Indonesia. Mastitis dapat dibedakan menjadi mastitis klinis dan mastitis subklinis. Dipandang dari sisi ekonomi, kejadian mastitis subklinis sangat penting karena menyebabkan penurunan produksi serta perubahan komposisi susu yang sangat signifikan sehingga mengakibatkan kerugian ekonomi yang besar (Halasa et al., 2007). MenurutKossaibati dan Esslemont (1997) serta Shahid et al. (2011), Kejadian mastitis subklinis di negara berkembang maupun negara majujuga sangat tinggi. Hal tersebut didukung oleh Varshney and Naresh (2004)yang menunjukkan bahwa kerugian setiap tahun pada industri susu di India mencapai kisaran 526 juta dolar Amerika dan kejadian mastitis subklinis bertanggung jawab sekitar $70 \%$ dari kerugian tersebut.

Penelitian Hirst et al. (1985) menunjukkan bahwa setiap kuartir ambing yang menderita mastitis subklinis produksi susu akan turun antara $10-15 \%$ per hari.Selain penurunan produksi susu, terjadi juga penurunan kualitas nutrisi susu dan bahkan diafkir, masa laktasi lebih pendek serta naiknyabiayapengobatan. Mastitis subklinis terjadi saat ambing terinfeksi dan jumlah sel lekosit mengalami peningkatan tetapi tidak menunjukkan gejala peradangan pada ambing (Smith, 2002).
Mastitis subklinis dikenali melalui perubahan komposisi susu serta pemeriksaan laboratorium (Islam et al. 2011). Kejadian mastitis subklinis dapat disebabkan berbagai macam faktor seperti kondisi kesehatan dan lingkungan sapi yang buruk serta adanya mikroorganisme yang dapat menjadi agen penyakit. Salah satu mikroorganisme penyebab mastitis adalah bakteri. Bakteri utama penyebab mastitis pada sapi adalah Streptococcus agalactiae, Streptococcus Streptococcus uberis dan Staphylococcus aureus (Quinn et al., 2002). Sedangkan menurut Barrett et al. (2005), bakteri Staphylococcus lain dapat mengakibatkan mastitis subklinis adalah Staphylococcus chromogenes, Staphylococcus haemolyticus, Staphylococcus hominis dan Staphylococcus epidermidis. Menurut Bochniarz et al. (2013) dan Bjork et al. (2014), Staphylococcus epidermidis dapat dimasukkan ke dalam kelompok coagulase-negative staphylococci (CNS) penyebab mastitis subklinis yang berdampak besar pada peternakan sapi perah. Staphylococcus epidermidis sebagai penyebab mastitis sub klinis di Indonesia jarang dilaporkan karena kebanyakan laporan penelitian terfokus pada Staphylococcus aureus sebagai penyebabnya. Oleh sebab itu peneliti mencoba melakukan isolasi dan identifikasi Staphylococcus epidermidis pada susu sapi penderita mastitis subklinis di kelompok ternak Koperasi Sarana Makmur, Wukirsari, cangkringan, Sleman, DIY.

\section{MATERI DAN METODE Materi}

Penelitian ini menggunakan 16 sampel susu sapi PFH yang berasal dari kandang kelompok peternakan Koperasi Sarana Makmur, Wukirsari, cangkringan, Sleman, DIY. Alat dan 
bahan berupa spuit, paddle, styrofoam box, reagen CMT.

Isolasi dan identifikasi bakteri menggunakan $\mathrm{NaCl}$ fisiologis, crystal violet, lugol, alkohol 95\%, air fuchsine, perhidrol $\left(\mathrm{H}_{2} \mathrm{O}_{2}\right) 3 \%$, aquadestilata dan plasma kelinci. Media pertumbuhan bakteri yang digunakan adalah Brain Heart Infussion (BHI), plat agar darah(PAD), Mac Conkey Agar(MCA), media gula-gula (laktosa, manitol, maltosa dan sukrosa).

\section{Metode}

Pengambilan sampel susu dilakukan di peternakan Koperasi Sarana Makmur, Wukirsari, cangkringan, Sleman, DIY. Sebelum dilakukan pengambilan sampel, ujung puting dibersihkan dengan alkohol dan dibiarkan mengering. Metode pemerahan dilakukan manual pada keempat kuartir ambing, pancaran pemerahan pertama dibuang dan kemudian masing masing sebanyak 10 $\mathrm{ml}$ dimasukan ke dalam spuit dan disimpan di dalam styrofoam box dan dikirim ke Balai Laboratorium Kesehatan Yogyakarta untuk dilakukan identifikasi dan uji resistensi bakteri.

Pengujian masitits subklinis dilakukan secara langsung di lokasi penelitian dengan menggunakan reagen CMT. Sampel sebanyak $2 \mathrm{ml}$ dari setiap ambing kemudian dimasukkan ke dalam paddle mastitis dan ditambahkan reagen CMT dengan jumlah yang sama pada setiap sampel. Setelah itu paddle mastitis digoyang searah jarum jam secara perlahan selama beberapa saat dan hasilnya kemudian diamati dibawah sinar matahari langsung. Kriteria penilaian uji CMT sesuai dengan metode Marshall et al. (1993), yaitu : negatif (-) dengan jumlah sel radang 0$200.000 / \mathrm{ml}$, trace dengan jumlah sel radang 150.000-500.000/ml, (+) dengan jumlah sel radang 400.000- 1.500.000/ml, (++) dengan jumlah sel radang 800.000-5.000.000/ml dan (+++) dengan jumlah sel radang lebih dari $5.000 .000 / \mathrm{ml}$.

Sampel susu sebanyak $2 \mathrm{ml}$ ditanam pada media $\mathrm{BHI}$ dan diinkubasi selama 24 jam pada temperatur $37^{\circ} \mathrm{C}$. Koloni yang tumbuh pada BHI kemudian ditanam di PAD dan MCA dilanjutkan dengan inkubasi selama 24 jam pada temperatur $37^{\circ} \mathrm{C}$ (Hendrix and Sirois, 2002). Koloni yang tumbuh pada PAD dan MCA kemudian ditanam pada media gula gula (Laktosa, manitol, maltosa dan sukrosa) serta Nutirent Agar (NA). Pengecatan gram dari koloni PAD dilakukan sesuai dengan metode Forbes et al. (2007).

Uji katalase sesuai dengan metode Hendrix and Sirois (2002) dilakukan untuk mengetahui kemampuan bakteri menghasilkan enzim katalase. Adanya enzim katalase ditunjukkan dengan timbulnya gelembung oksigen pada gelas obyek karena terurainya hidrogen peroksida menjadi air dan oksigen. Uji koagulase dilakukan menurut Forbes et al. (2007) untuk membedakan bakteri Staphylococcus aureus yang bersifat positif koagulase dengan Staphylococcus epidermidis yang bersifat koagulase negatif. Koagulase positif ditunjukkan dengan terbentuknya gumpalan secara makroskopik dalam waktu sekitar 10 detik pada plasma kelinci.

DNase dilakukan sesuai dengan Forbes et al. (2007). Uji DNase dilakukan dengan menginokulasi biakan bakteri yang akan diuji kemudian di streak pada media DNase agar dilanjutkan dengan inkubasi pada suhu $35^{\circ} \mathrm{C}$ selama $13-24$ jam. Hasil positif ditunjukkan dengan perubahan warna media dari hijau menjadi tidak berwarna. 
HASIL DAN PEMBAHASAN

Limabelas dari 16 (93,75\%) sampel susu yang telah diuji dengan reagen
CMT menunjukkan positif mastitis subklinis (Tabel 1).

Tabel 1. Hasil uji CMT sampel susu

\begin{tabular}{ll}
\hline Sampel & Hasil uji \\
\hline 1 & - \\
- & Trace \\
2 & + \\
9 & ++ \\
4 & +++ \\
\hline$\sum=16$ &
\end{tabular}

Menurut Sharma et al. (2010), hasil positif uji CMT ditandai dengan terbentuknya jonjot atau gumpalan pada susu akibat reaksi antara CMT dengan sel sel radang dalam susu. Hasil penelitian menunjukkan bahwa kejadian mastitis subklinis di peternakan Koperasi Sarana Makmur, Wukirsari, cangkringan, Sleman, DIY sangatlah tinggi. Hasil penelitian oleh Supar (1997) juga menunjukkan bahwa prevalensi mastitis subklinis untuk DIY, Jawa Tengah dan Jawa Timur diperkirakan berkisar antara 37-67\%. Lebih lanjut menurut Poeloengan (2009), kejadian penyakit mastitis pada sapi perah di Indonesia sangat tinggi yaitu sekitar $85 \%$ dan sebagianbesar penyakit mastitis yang sering menyerang sapi perah adalah mastitis subklinis. Tingginya kejadian mastitis subklinis dari penelitian ini kemungkinan besar diakibatkan oleh tata kelola peternakan sapi perah yang kurang memadai seperti buruknya higiene pemerahan dan sanitasi kandang. Hal tersebut didukung oleh Shittu et al. (2012) menyatakan bahwa faktor-faktor seperti hygiene pemerahan dan sanitasilingkungan berperan secara nyata pada kejadian mastitis subklinis di peternakan sapi perah. Nurhayati dan Martindah (2015) juga menambahkan bahwa kejadian mastitis subklinis di Indonesia sangatlah tinggi karena tata kelola peternakan yang masih kurang baik. Hasil penelitian oleh Aprilia et al. (2016) juga menyatakan bahwa diperlukan kegiatan hygiene pemerahan seperti teat dipping pada akhir pemerahan dengan tujuan menekan jumlah cemaran bakteri yang dapat masuk ke dalam ambing dan mencemari susu. Penelitian oleh Kurniawan et al. (2013) juga menunjukkan bahwa teat dipping akan menurunkan tingkat kejadian mastitis. Kemungkinan lain tingginya kejadian mastitis subklinis dalam penelitian ini adalah penggunaan mesinperah di kandang kelompok yang jumlahnya kurang mencukupi sehinggagunakan secara bergantian. Kemungkinan tersebut didukung oleh hasil penelitian Bava et al. (2009) yang menyatakan bahwa kebersihan mesin perah merupakan titik kritis yang mempengaruhi jumlah bakteri dalam susu. Lebih lanjut Azevedo et al. (2016) menyatakan bahwa pencucian mesin perah dengan air panas dapat menurunkan jumlah bakteri dalam susu.

Mastitis subklinis pada sapi perah sering terjadi akibat infeksi Staphylococcus epidermidis yang termasuk dalam kelompok coagulasenegative staphylococci. Coagulasenegative staphylococci adalah kelompok flora normal kulit ruminansia yang virulensinya rendah, namundemikian dapat berperan sebagai 
sumber tetap infeksi bakteri karena membentukkoloni pada puting dan sering menghasilkan respon keradangan yang dapat diukur dengan peningkatan sel somatik (Thorberg et al., 2009). Lebih lanjut, Thorberg (2008) juga menyatakan bahwa pengendalian mastitis subklinis yang diakibatkan oleh kelompok coagulase-negative staphylococci tidaklah mudah karena banyaknya spesies dalam kelompok tersebut. Hasil isolasi dan identifikasi 15 sampel susu penderita mastitis subklinis pada penelitian ini diperoleh satu atau $(6,66 \%)$ Staphylococcus epidermidis (Tabel 2).

Tabel 2. Hasil uji Identifikasi bakteri Staphylococcus epidermidis

\begin{tabular}{ll}
\hline Uji & Hasil \\
\hline BHI & keruh \\
Katalase & + \\
Koagulase & - \\
Laktosa & - \\
Manitol & - \\
Maltosa & - \\
Sukrosa & - \\
\hline
\end{tabular}

Hasil penelitian Kudinha dan Simango (2002) juga menunjukkan prosentase yang rendah, dimana $7,4 \% S$. epidermidis terisolasi dan teridentifikasi pada sapi penderita mastitis subklinis di propinsi Mashonaland dan Manicaland, Zimbabwe. Sedangkan hasil penelitian sebaliknya diperoleh Supar dan Ariyanti (2008) pada sapi perah penderita mastitis subklinis yang menunjukkan bahwa 91,5\% disebabkan oleh Streptococcus agalactia, Staphylococcus aureusdan Staphylococcus epidermidis. Prosentase yang tinggi juga diperoleh dalam penelitian pada kambing penderita mastitis di peternakan kambing komersial di Itali. Sebanyak 48\% mastitis pada kambing tersebut disebabkan oleh Staphylococcus epidermidis (Moroni et al., 2005). Hasil isolasi dan identifikasi Staphylococcus epidermidis dalam penelitian ini memiliki kemungkinan juga dipengaruhi oleh hygiene pemerahan. Menurut Kloos (1980), Staphylococcus epidermidis adalah salah satu Staphylococcus sp yang paling umum ditemukan pada kulit manusia. Oleh sebab itu ada kemungkinan bahwa terjadinya infeksi ambing disebabkan oleh Staphylococcus epidermidis dari manusia terutama dari pemerah (Watts and Owens, 1989). Pernyataan tersebut dikuatkan oleh hasil penelitian Thorberg et al. (2006) yang menunjukkan bahwa isolat strain Staphylococcus epidermidis dari susu kelompok sapi yang diteliti sama dengan yang diisolasi dari tangan dan siku pemerah.

\section{KESIMPULAN}

Kejadian mastitis subklinis peternakan Koperasi Sarana Makmur, Wukirsari, cangkringan, Sleman, DIY menunjukkan angka yang tinggi $(93,75 \%)$ dan kemungkinan besar disebabkan oleh tata kelola peternakan yang masih kurang memadai. Tingginya kejadian mastitis subklinis tersebut kemungkinan disebabkan oleh bakteri yang lain karena hanya 6,66\% yang disebabkan oleh Staphylococcus epidermidis. Tata kelola Koperasi Sarana Makmur, Wukirsari, cangkringan, Sleman, DIY perlu ditingkatkan supaya tingkat kejadian mastitis sublinis dapat diturunkan sehingga hasil produksi susu 
secara keseluruhan meningkat baik dalam hal jumlah maupun kualitas.

\section{DAFTAR PUSTAKA}

Aprilia, P.R., Santoso, S.A.B., dan Harjanti, D.W. 2016.Jumlah Staphylococcus aureus dan kandungannutriensusuakibat dipping putingmenggunakan ekstrak daun belimbing wuluh (Averrhoa bilimbi Linn) pada sapiperahpenderita mastitis subklinis. Jurnal Ilmu-Ilmu Peternakan, 26(1), 43-51.

Azevedo, C., Pacheco, D., Soares, L., Romão, R., Moitoso, M., Maldonado, J., Guix, R., andSimões, J. 2016. Prevalence of contagious and environmental mastitis-causing bacteria in bulk tank milk and its relationships with milking practices of dairy cattle herds in São Miguel Island (Azores). Trop Anim Health Prod, 48(2), 451-459.

Barrett, D.J., Healy, A.M., Leonard, F.C., and Doherty, M.L. 2005. Prevalence of pathogens causing subclinical mastitis in 15 dairy herds in the Republic of Ireland. Ir Vet J., 58(6), 333-337.

Bava, L., Zucali, M., Brasca, M., Zanini, L., and Sandrucci, A. 2009. Efficiency of cleaning procedure of milking equipment and bacterial quality of milk. Italian Journal of Animal Science, 8(2), 387389.

Bjork, B., Båge, R., Kanyima, B.M., André, S., Nassuna-Musoke, M.G., Owiny, D.O., and Persson, Y. 2014. Characterization of coagulase negative staphylococci from cases of sub- clinical mastitis in dairy cattle in Kampala, Uganda. Ir Vet $J$, 67(12), 1-3.

Bochniarz, M., Wawron, W., and Szczubiał, M. 2013. Coagulasenegative staphylococci (CNS) as an aetiological factor of mastitis in cows. Pol J Vet Sci., 16(3), 487-92.

Forbes, B.A., Sahm, D.F., and Weissfeld, A.S. 2007. Diagnostic Microbiology. Ed. 12. Missouri: Mosby Elsevier. 223-258

Halasa, T., Huijps, K., Osteras, O., and Hogeveen, H. 2007. Economic effects of bovine mastitis and mastitis management: A review. Vet. Q., 29(1), 18-31.

Hendrix, C.M., and Sirois, M. 2002. Laboratory Procedures for Veterinary Technicians. 5th Edition. Mosby, Elsevier.

Hirst, R. G., Nurhadi, A., Rompis, A., Wins, J., Supartono, and Setadi, Y. 1985. The detection subclinical mastitis in the tropic and the assessment of associated milk production losses. Proceedings of the third AAAP animal science congress. Seoul, Korea. (I), 498- 500

Islam, M.A., Islam, M.Z., Islam, M.A., Rahman, M.S., and Islam, M.T. 2011. Prevalence of subclinical mastitis in dairy cows in selected areas of Bangladesh. Bangladesh J Vet Med., 9(1), 73-78.

Kloos, W. 1980. Natural populations of the genus Staphylococcus. Annual review of microbiology, 34 , 
$559-592$.

https://doi.org/10.1146/annurev. mi.34.100180.003015

Kossaibati, M. A., and Esslemont, R. J. 1997. The costs of production diseases in dairy herds in England. The Veterinary Journal, 154(1), 41-51.

Kudinha, T., and Simango, C. 2002. Prevalence of coagulasenegative staphylococci in bovine mastitis in Zimbabwe. Journal of the South African Veterinary Association, 73(2), 62-65.

Kurniawan, I., Sarwiyono, dan Surjowardojo, P. 2013.Pengaruh teat dipping menggunakan dekok daun kersen (Muntingiacalabura L.) terhadaptingkatkejadian mastitis. Jurnal IlmuIlmu Peternakan, 23(3), 27-31.

Marshall, R.T., Edmondson, J. E., and Steevens, B. 1993. Using the California Mastitis Test. https://extension2.missouri.edu/g 3653

Moroni, P., Pisoni, G., Antonini, M., Ruffo, G., Carli, S., Varisco, G., and Boettcher, P. 2005. Subclinical Mastitis and Antimicrobial Susceptibility of Staphylococcus caprae and Staphylococcus epidermidis Isolated from Two Italian Goat Herds. J. Dairy Sci, 88(5), 1694-1704.

Nurhayati, I.S., dan Martindah, E. 2015. Pengendalian Mastitis Subklinis melalui Pemberian Antibiotik Saat Periode Kering pada Sapi Perah. Wartazoa, 25(2): 065074.
Poeloengan, M. 2009. Aktivitas air perasan dan ekstrak etanol daun encok terhadap bakteri yang diisolasidari sapi mastitis subklinis. Dalam: Seminar Nasional Teknologi Peternakan dan Veteriner 2009. Balai Besar Penelitian Veteriner. Bogor. 300-305.

Quinn, P.J., Carter, M.E., Markey, B.K., and Carter, G.R. 2002.Clinical Veterinary Microbiology. Virginia, USA: Harcourt Publishers, 331-344.

Shahid, M., Sabir, N., Ahmed, I., Khan, R.W., Irshad, M., Rizwan, M., and Ahmed, S. 2011. Diagnosis of Subclinical Mastitis In Bovine Using Conventional Methods And Electronic Detector. ARPN Journal of Agricultural and Biological Science, 6(11), 18-22.

Sharma, N., Pandey, V., andSudhan, N.A. 2010. Comparison of some indirect screening test for detection of subclinical mastitis in dairy cows. Bulgarian Journal of Veterinary Medicine, 13(2), 98-103.

Shittu, A., Abdullahi, J., Jibril, A., Mohammed, A. A., \& Fasina, F. O. 2012. Sub-clinical mastitis and associated risk factors on lactating cows in the Savannah Region of Nigeria. BMC Veterinary Research, 8(1), 134.

Smith, B.P. 2002. Large Animal Internal Medicine. Edisi ke 3. St. Louis, Missouri: Mosby, 10251037.

Supar. 1997. Mastitis subklinis pada sapiperah di Indonesia: Masalah 
dan pendekatannya. Wartazoa, $6(2), 48-52$.

Supar, dan Ariyanti, T. 2008. Kajian pengendalian mastitis subklinis pada sapiperah. Dalam: Diwyanto K, Wina E, Priyanti A, Natalia L, Herawati T, Purwandaya B, penyunting. Prosiding Lokakarya Nasional Prospek Industri Sapi Perah Menuju Perdagangan Bebas 2020. Jakarta, 21 April 2008. Bogor (Indonesia): Puslitbangnak. 360-366.

Thorberg, B.M., Kuhn, I., Aarestrup, F.M. Brandstrom, B., Jonsson, P., andDanielsson-Tham, M.L. 2006.APheno- and genotyping of Staphylococcus epidermidis isolated from bovine milk and human skin. Veterinary Microbiology, 115(1-3), 163-172.

Thorberg, B.M. 2008. CoagulaseNegative Staphylococci in Bovine Sub-Clinical Mastitis. Thesis. Department of Biomedical Sciences and Veterinary Public Health Swedish University of Agricultural Sciences.

Thorberg, B.M., Danielsson-Tham, M.L., Emanuelson, U., and Waller, K. P. 2009. Bovine subclinical mastitis caused by different types of coagulase-negative staphylococci. J. Dairy Sci, 92(10), 4962-4970.

Varshney, J.P., and Naresh, R. 2004. Evaluation of homeopathic complex in the clinical management of udder diseases of riverine buffaloes. Homeopathy, 93(1), 17- 20.

Watts, J.L., and Owens, W.E. 1989. Prevalence of staphylococcal species in four dairy herds. Res. Vet. Sci, 46 (1), 1-4. 